\title{
Aquinas on Infinite Multitudes
}

\author{
RICHARD L. CARTWRIGHT
}

Massachusetts Institute of Technology

To my knowledge, it is only in $S T$ I, 7, 4 that Aquinas considers quite on its own the question whether actually infinite multitudes are possible. ${ }^{1}$ There he declares, and claims to demonstrate, that it is impossible for there to be an actually infinite multitude (impossibile est ... esse multitudinem infinitam in actu). But later, at $S T$ I, 46, 2 ad 7, he says that it is not impossible to proceed to infinity per accidens in efficient causes (per accidens in infinitum procedere in causis agentibus non reputatur impossibile). The apparent inconsistency is the topic of this paper, and I shall begin by explaining in some detail how it arises.

\section{I}

The question under discussion in $S T$ I, 46, 2 is whether it is a matter of faith that the world began. Aquinas holds that it is. But he must answer objections, of which the seventh is a purported demonstration that the world began. It reads:

If the world was eternal, generation was from eternity. Therefore one man was begotten of another to infinity. But the father is an efficient cause of the son, as is said in Physics II. Therefore in efficient causes there is an infinite series-which is disproved in Metaphysics II. ${ }^{2}$

As it stands, the objection is silly: eternity of the world would hardly require an endless generation of human beings, as Aquinas points out elsewhere. ${ }^{3}$ Here,

1. Here and throughout, $S T=$ Summa theologiae, Leonine text, as contained in Sancti Thomae de Aquino: Summa Theologiae, (Roma: Editiones Paulinae, 1962). For translations I have relied on St. Thomas Aquinas: Summa Theologica, trans., Fathers of the English Dominican Province, 3 vols., (New York: Benziger, 1947); St. Thomas Aquinas: Summa Theologiae, Latin text and English trans., (New York: Blackfriars, in cooperation with McGraw Hill, 1964-1974); and especially Anton C. Pegis, Basic Writings of Saint Thomas Aquinas (New York: Random House, 1945). But I have not followed any of these faithfully.

2. "Si mundus fuit aeternus, et generatio fuit ab aeterno. Ergo unus homo genitus est ab alio in infinitum. Sed pater est causa efficiens filii, ut dicitur in II Phys. Ergo in causis efficientibus est procedere in infinitum: quod improbatur in II Metaphys."

3. Thus in De aeternitate mundi he says that "God could have made the world without men and souls; or He could have made men at the time He did make them, even though He had made all the rest of the world from eternity" (as translated in Cyril Vollert, et al., On the Eternity of the World [Milwaukee: Marquette University Press, 1964], p. 25). 
however, he responds in effect to a stronger version, which can be put succinctly with the help of a little technical apparatus.

Let $\mathrm{C}$ be the relation of efficient causation, that is, the relation that $\mathrm{x}$ bears to $\mathrm{y}$ just in case $\mathrm{x}$ is an efficient cause of $\mathrm{y}$. And let an infinitely descending $C$-sequence be a sequence

$$
\ldots \mathrm{x}_{2}, \mathrm{x}_{1}, \mathrm{x}_{0}
$$

such that $x_{i}$ bears $C$ to $x_{i-1}$, for each positive integer $i$. The objection in its stronger version may then be put as follows: if it is possible that the world did not begin, then it is possible that there should have been an infinitely descending C-sequence; but as is shown in Metaphysics II, infinitely descending $\mathrm{C}$-sequences are not possible; therefore, it is not possible that the world did not begin. Aquinas answers at some length:

In efficient causes it is impossible to proceed to infinity per se-as if the causes per se required for some effect were multiplied to infinity; for instance, if a stone were moved by a stick, the stick by the hand, and so on to infinity. But it is not impossible to proceed to infinity per accidens in efficient causes; for instance, if all the causes multiplied to infinity have the order of only one cause, but their multiplication is per accidens: for example, as a craftsman acts by means of many hammers per accidens, because one after another is broken. It is accidental, therefore, that one particular hammer should act after the action of another. And it is likewise accidental to this man as generator that he is generated by another; for he generates as a man, and not as son of another man. For all men generating hold one grade in the order of efficient causes, namely the grade of a particular generator. Hence it is not impossible that man is generated by man to infinity; but such a thing would be impossible if the generation of this man depended upon this man, and on an elementary body, and on the sun, and so on to infinity. 4

The point of the illustration concerning the craftsman who uses infinitely many hammers is not altogether clear. Let us imagine, with Peter Geach, that the craftsman is in particular "an immortal blacksmith who has been making horse-

4. "In causis efficientibus impossibile est procedere in infinitum per se; ut puta si causae quae per se requiruntur ad aliquem effectum, multiplicarentur in infinitum; sicut si lapis moveretur a baculo, et baculus a manu, et hoc in infinitum. Sed per accidens in infinitum procedere in causis agentibus non reputatur impossibile; ut puta si omnes causae quae in infinitum multiplicantur, non teneant ordinem nisi unius causae, sed earum multiplicatio sit per accidens; sicut artifex agit multis martellis per accidens, quia unus post unum frangitur. Accidit ergo huic martello, quod agat post actionem alterius martelli. Et similiter accidit huic homini, inquantum generat, quod sit generatus ab alio: generat enim inquantum homo, et non inquantum est filius alterius hominis; omnes enim homines generantes habent gradum in causis efficientibus, scilicet gradum particularis generantis. Esset autem impossible, si generatio huius hominis dependeret ab hoc homine, et a corpore elementari, et a sole, et sic in infinitum." (See also, ST I-II, 1, 4.) 
shoes from all eternity, and has naturally worn out no end of hammers in the process"; and let us agree that "the making of the horseshoe now on the anvil depends only upon the smith as efficient cause and the hammer currently in use as instrument," so that "though no end of hammers have in fact been broken in the past, they have nothing to do with the [present] case". 5 The difficulty is that we do not have an imagined example of an infinitely descending $\mathrm{C}$-sequence. I think Aquinas would have said that each hammer is a cause, though one that acts through the action of the smith. ${ }^{6}$ And the hammers do make up an imagined infinitely descending temporal sequence. But such descending $\mathrm{C}$-sequences as can be extracted from the illustration are finite: none of the hammers bears $C$ to any other, and no horseshoe is described as the start of an infinitely descending C-sequence.

Maybe the illustration is to be understood somewhat differently: an immortal smith again, but this time one who has been at work on a single horseshoe from eternity and who has, in an extraordinary run of bad luck, broken no end of hammers in the process. Here we imagine not only that there have been infinitely many hammers used but also that the horseshoe now on the anvil has an infinite causal ancestry. Still no infinitely descending $\mathrm{C}$-sequence, however; for again, none of the hammers can be regarded as bearing $\mathrm{C}$ to any other.

Maybe, then, Aquinas has given us an overly succinct description of an illustration that Averroes used and that may have been in the air. In order to explain the kind of case in which, "according to philosophical doctrine," an infinite regress of efficient causes is possible, Averroes said that

when an artisan produces successively a series of products of craftsmanship with different instruments, and produces these instruments through instruments and the latter again through other instruments, the becoming of these instruments one from another is something accidental, and none of these instruments is a condition for the existence of the product of craftsmanship except the first instrument which is in immediate contact with the work produced.... And the instrument with which this instrument is produced will be necessary for the production of this instrument, but will not be necessary for the production of the product of craftsmanship unless accidentally. ${ }^{7}$

Simplifying somewhat, one may this time imagine the immortal smith producing the present horseshoe with a hammer he has produced with another hammer, which latter hammer he has produced with still another, and so on endlessly. With that, we do get an imaginary case of an infinitely descending $\mathrm{C}$-sequence.

5. G. E. M. Anscombe and P. T. Geach, Three Philosophers (Oxford: Blackwell, 1961), p. 112.

6. See $S T$ I, $36,3$.

7. Tahafut al-Tahafut, Fourth Discussion, as translated by Simon van den Bergh, Averroes's Tahafut al-Tahafut (London: Luzac, 1954), 1:159. I say the illustration "may have been in the air," in order to avoid giving the impression that Aquinas might have read Tahafut al-Tahafut. Apparently that work was not translated into Latin until the fourteenth century. 
Whatever in the end is to be made of Aquinas's first illustration, his second leaves no doubt that he thought it possible for there to be infinitely descending C-sequences: it is not impossible for man to be generated from man to infinity. But such a sequence would be ordered per accidens, not per se. And we are expressly told that it is impossible for there to be an infinitely descending Csequence which is per se ordered. What is the intended distinction?

Perhaps because it had been invoked by others before him Aquinas is less than fully explicit about the nature of the intended distinction. ${ }^{8}$ But certain of his remarks, together with some things that Duns Scotus says, make it reasonably clear that a per se ordered descending C-sequence is supposed to satisfy three conditions. First, the restriction of $\mathrm{C}$ to the terms of the sequence is transitive, so that any term of the sequence bears $C$ to such terms as may follow it in the sequence. I take it that this lies behind Aquinas's remark that "when there are many ordered causes, it is necessary that, while the effect depends first and principally on the first cause, it also depends in a secondary way on all the intermediate causes" (ST I, 104, 2). ${ }^{9}$ This is also presumably what Scotus meant when he said that "if anything is prior to the prior, it is prior to the posterior". 10 Second, the causal action of any term in the sequence is simultaneous with that of any other term in the sequence, so that there is some one time at which all the terms of the sequence exist. As Scotus says, "all the causes per se ordered are necessarily required simultaneously for that which is caused". 11 Third, any "intermediate" - that is, any term $\mathrm{y}$ of the sequence for which there are terms $\mathrm{x}$ and $\mathrm{z}$ in the sequence such that $\mathrm{xCy}$ and $\mathrm{yCz}$ - exercises its causality by virtue of being caused by its immediate predecessor in the sequence. This last condition is hard to state clearly, but perhaps the idea is sufficiently conveyed by Aquinas's example: the hand moves the stick and thereby the stick moves the stone. He puts the point elsewhere by saying that "if there are many agents in order, the second agent [that is, any intermediate] always acts in virtue of the first; for the first agent moves the second to act" (ST I, 105, 5). ${ }^{12}$ And Scotus says that "in per se [ordered causes], the second, in so far as it causes, depends on the first." 13

Though hard to state, the third condition is evidently to be regarded as fundamental. Scotus says that simultaneity in causal action follows from it. Apparently with approval, Aquinas reports Aristotle to the same effect:

8. See, for example, Maimonides, Guide for the Perplexed I, 73, Eleventh Proposition.

9. "Cum enim sunt multae causae ordinatae, necesse est quod effectus dependeat primo quidem et principaliter a causa prima; secundario vero ab omnibus causis mediis." (See also, In octo libros Physicorum expositio [hereafter In Phys.] VIII, 9 [1039].)

10. De primo principio, II, argument for the second conclusion.

11. De primo principio, III, argument for the second conclusion.

12. Si sint multa agentia ordinata, semper secundum agens agit in virtute primi: nam primum agens movet secundum ad agendum.

13. De primo principio, III, argument for the second conclusion. In the same place Scotus states a fourth condition, namely, that "in per se ordered [causes] the causality is of another nature and order, because the higher is more perfect." 
Let A be something which is moved in respect to place by something B. And $\mathrm{B}$ is moved by $\mathrm{C} ; \mathrm{C}$ is moved by $\mathrm{D} ; . .$. It is clear that when a thing moves because it is moved, the mover and the mobile object are moved simultaneously. For example, if the hand by its own motion moves a staff, the hand and the staff are moved simultaneously. Hence B is moved simultaneously when A is moved; and for the same reason when B is moved, C is moved simultaneously; and when $\mathrm{C}$ is moved, D is moved simultaneously. Therefore the motions of $\mathrm{A}$ and of all the others are simultaneous and in the same time. ${ }^{14}$

I conjecture that neither Aquinas nor Scotus ever played with dominoes. The finger by moving moves the first domino, which by moving moves the second, and so on down the line; but even when the line is not very long, the finger's motion visibly stops before the last domino falls.

It is clear in any case that a descending C-sequence in which $x_{n}$ begets $x_{n-1}$ satisfies none of these conditions. In particular, not the third: it is not by virtue of Abraham's act of begetting that Isaac begets Jacob.

Now, it is not the case that infinitely descending R-sequences always have infinitely many terms. But it is the case for nonempty relations that are transitive and irreflexive. To see that this is so, we may think of an infinitely descending sequence as a function the domain of which is the set of natural numbers and the range of which consists of what I have been calling the "terms" of the sequence. Assume, then, that $\mathrm{R}$ is a nonempty, irreflexive, and transitive relation, and let $\mathrm{f}$ be an infinitely descending $R$-sequence. To show that the range of $f$ is infinite, it suffices to show that $f$ is one-one, that is, that if $f(n)=f(m)$, then $n=m$. If $n$ is not $\mathrm{m}$, then with no loss of generality we may suppose $\mathrm{n}$ to be less than $\mathrm{m}$. But then by transitivity of $R, f(m)$ will bear $R$ to $f(n)$, which is impossible by the assumed irreflexivity of $\mathbf{R}$.

So if an irreflexive and transitive relation $\mathrm{R}$ admits of an infinitely descending R-sequence, then infinitely many things are in the field of R. But we cannot conclude at once that infinitely many things are in the field of $\mathrm{C}$. No doubt $\mathrm{C}$ is irreflexive: Aquinas certainly took it to be, 15 and there is no good reason to disagree. It is obvious, however, that $\mathrm{C}$ is not transitive: begetting is included in efficient causation, but though Abraham begot Isaac and Isaac begot Jacob, Abraham did not beget Jacob. On the other hand, the ancestral of $C$ is of course transitive: the ancestral $R^{*}$ of a relation $R$ is the relation that $x$ bears to $y$ just in case there is a finite sequence

$$
\mathrm{x}_{0}, \mathrm{x}_{1}, \ldots, \mathrm{x}_{\mathrm{n}}
$$

such that

14. In Phys. VII, 2 (891); as translated by Richard J. Blackwell, Richard J. Spath, and W. Edmund Thirlkel, Commentary on Aristotle's Physics by St. Thomas Aquinas (New Haven: Yale University Press, 1963), p. 426.

15. See, for example, $S T$ I, 2, 3, secunda via. 


$$
\mathrm{xRx}_{0} \mathrm{Rx}_{1} \mathrm{R} \ldots \mathrm{Rx}_{\mathrm{n}} \mathrm{R}_{\mathrm{y}}
$$

and evidently ancestrals are always transitive. Now, the ancestral of an irreflexive relation is not always itself irreflexive. But $\mathrm{I}$ can see no good reason to doubt that $\mathrm{C}^{*}$ is irreflexive; and since $\mathrm{C}$ is included in $\mathrm{C}^{*}$, there is an infinitely descending $\mathrm{C}$-sequence only if there is an infinitely descending $\mathrm{C}^{*}$-sequence. So if there is an infinitely descending $\mathrm{C}$-sequence, then there are infinitely many things in the field of $C^{*}$. But the field of $C^{*}$ is the field of $C$.

So if it is possible that there should be an infinitely descending $\mathrm{C}$-sequence, it is possible that there should be infinitely many things in the field of $\mathrm{C}$. Yet Aquinas asserts at $S T$ I, 7, 4 that an actually infinite multitude is impossible.

The assertion comes on the heels of a brief statement of a contrary view, which Aquinas attributes to Avicenna and Algazali. He says that according to their view

it is impossible for there to be an actually infinite multitude pe se, but an infinite multitude per accidens is not impossible. A multitude is said to be infinite per se when an infinite multitude is required for something. And this is impossible, because it would require that something be dependent on infinitely many things; hence its generation would never be completed, for it is not possible to traverse what is infinite. A multitude is said to be infinite per accidens when it is not required for something that there be infinitely many things, but there do happen to be.

The impossibility of an actually infinite multitude per se may be illustrated

in the work of a smith, for which is required a certain multitude per se, namely, art in the soul, a moving hand, and a hammer. But if this were to be multiplied to infinity, the smith's work would never be completed, because it would depend on an infinity of causes.

On the other hand,

the multitude of hammers which results when one hammer is broken and replaced by another is a multitude per accidens; for it happens that many hammers are used, and it matters none whether one or two or several are used-or infinitely many, if the work goes on for an infinite time. In this way they asserted that it is possible for there to be an actually infinite multitude per accidens. ${ }^{16}$

16. "Quidam enim, sicut Avicenna et Algazel, dixerunt quod impossibile est esse multitudinem actu infinitam per se: sed infinitam per accidens multitudinem esse, non est impossibile. Dicitur enim multitudo esse infinita per se, quando requiritur ad aliquid ut 
Aquinas comments at once: "But this is impossible" (Sed hoc est impossible). But what does he thereby declare to be impossible?

He cannot intend to reject the possibility that an immortal smith should in the course of his work use endlessly many hammers. For that is just the sort of thing which at $S T$ I, 46, 2, ad 7 is explicitly said to be a possibility. The illustration must be allowed to stand, on pain of inconsistency. But then the infinitely many hammers must not, even per imaginationem, constitute an actually infinite multitude.

Evidently the key word is actually, and the work it does appears to be brought out in Aquinas's response to the first objection in ST I, 7, 4. That objection reads:

It is not impossible for a potentiality to be made actual. But number can be multiplied to infinity. Therefore it is possible for an actually infinite multitude to exist. 17

If some quantifier trickery is at work, Aquinas ignores it:

Whatever exists potentially is made actual according to its mode of being. For instance, a day is reduced to act successively, and not all at once. Likewise the infinite in multitude is reduced to act successively, and not all at once, because every multitude can be succeded by another multitude to infinity. ${ }^{18}$

There is no one time at which the whole of today is actual. Not any time during the day, surely; and surely not at some time yesterday or tomorrow. Just so, Aquinas seems to say, with an infinite multitude. There is not-indeed, there cannot be-some one time at which all the things in the multitude are actually in existence, for it is of the nature of the infinite to exist successively, not all at once.

We saw some time back that in a per se ordered descending $\mathrm{C}$-sequence the

multitudo infinita sit. Et hoc est impossibile esse: quia sic oporteret quod aliquid dependeret ex infinitis; unde eius generatio nunquam compleretur, cum non sit infinita pertransire. Per accidens autem dicitur multitudo infinita, quando non requiritur ad aliquid infinitas multitudinis, sed accidit ita esse. Et hoc sic manifestari potest in operatione fabri, ad quam quaedam multitudo requiritur per se, scilicet quod sit ars in anima, et manus movens, et martellus. Et si haec infinitum multiplicarentur, nunquam opus fabrile compleretur: quia dependeret ex infinitis causis. Si multitudo martellorum quae accidit ex hoc quod unum frangitur et accipitur aliud, est multitudo per accidens: accidit enim quod multis martellis operetur; et nihil differt utrum uno vel duobus vel pluribus operetur, vel infinitis, si infinito tempore operaretur. Per hunc igitur modum, posuerunt quod possibile est esse actu multitudinem infinitam per accidens."

17. "Non enim est impossibile id quod est in potentia reduci ad actum. Sed numerus est in infinitum multiplicabilis. Ergo non est impossible esse multitudinem infinitam in actum."

18. " . . . unumquodque quod est in potentia, reducitur in actum secundum modum sui esse: dies enim non reducitur in actum ut sit tota simul, sed successive. Et similiter infinitum multitudinis non reducitur in actum ut sit totum simul, sed successive: quia post quamlibet multitudinem, potest sumi alia multitudo in infinitum." 
causal action of any term in the sequence is simultaneous with that of any other term in the sequence and that there must therefore be some one time at which all the terms of the sequence exist. This is enough to show that per se ordered infinitely descending C-sequences are not possible. But I doubt that it was Aquinas's only reason, or even his most fundamental. Avicenna and Algazali had argued against the possibility of a per se ordered infinitely descending $\mathrm{C}$-sequence on the ground that in such a sequence the ultimate effect would depend on an actual infinity of causes and hence could never obtain. It is infinite dependency that in their view makes for the impossibility. I think Aquinas agrees. In Summa contra gentiles (II, 38), again in response to a purported proof of the noneternity of the world, he says that

according to the philosophers, it is impossible to proceed to infinity in the order of efficient causes which act together at the same time, because in that case the effect would have to depend on an infinite number of actions simultaneously existing. And such causes are essentially infinite, because an infinity of them is required for the effect. 19

I think he speaks here for himself, not only for "the philosophers." And so I take him to be saying that independently of the question whether there can exist actually infinite multitudes, it can be seen that no per se ordered C-sequence can be infinitely descending. But of course once that question has been settled, an additional argument is available: the existence of a per se ordered infinitely descending $\mathrm{C}$-sequence would require that there be an actually infinite multitude.

\section{III}

So it seems to be open to Aquinas to allow that there are infinite multitudes. And indeed he does. An instance occurs in ST I, 7, 4 itself. There the second objection reads:

It is possible for any individual of any species to be actual. But the species of figure are infinite. Therefore it is possible for there actually to be infinitely many figures. ${ }^{20}$

And Aquinas answers:

The species of figure are infinite by the infinitude of number, for the species of figure are the trilateral, the quadilateral, and so on. Hence as an infinitely

19. “. . . causas agentes in infinitum procedere est impossibile, secundum philosophos, in causis simul agentibus: quia oporteret effectum dependere ex actionibus infinitis simul existentibus. Et huiusmodi sunt causae per se infinitae: quia earum infinitas ad causatum requiritur."

20. ". . . Praeterea, cuiuslibet speciei possible est esse aliquod individuum in actu. Sed species figurae sunt infinitae. Ergo possibile est esse infinitas figuras in actu." 
numberable multitude is not reduced to act all at once, neither is the multitude of figures. ${ }^{21}$

Here, notice, there is no denial that the species of figure are infinite. But a species of figure is not as such actual. It is "reduced to act" just in so far as some body, or surface of some body, is of that species-is trilateral, quadrilateral, or a chiliagon. It is possible that each of the infinitely many species of figure should be thus reduced to act, but it is not possible that there should be a time at which all are. Notice also that Aquinas speaks of "the infinitude of number," thereby seeming to suggest that there are infinitely many numbers. In fact we find him saying elsewhere that "there are infinitely many even numbers"-and adding, interestingly, that "yet the even numbers and the odd numbers taken together are more than the even numbers." 22 I take it that a number is "reduced to act" by there being some actual multitude of which it is the number-by there being a dozen cookies in the jar, or a thousand million angels.

Yet I think Aquinas is not out of the woods: it is supposed to be demonstrable that there can be no actually infinite multitudes. But even if they are proofs, Aquinas's arguments cause trouble. They read as follows:

[E]very multitude must be in some species of multitude. Now the species of multitude are according to the species of numbers. But no species of number is infinite, for every number is multitude measured by one. Hence it is impossible that there be an actually infinite multitude, either per se or per accidens. Furthermore, every multitude in the world is created, and everything created is comprehended under some definite intention of the Creator; for no agent acts aimlessly (in vanum). Hence it is necessary that everything created be comprehended under a certain number. Therefore it is impossible for there to be an actually infinite multitude, even per accidens. 23

The first argument is the more fundamental, I think, and so I shall concentrate on it.

21. “. . species figurarum habent infinitatem ex infinitate numeri: sunt enim species figurarum, trilaterum, quadrilaterum, et sic inde. Unde, sicut multitudo infinita numerabilis non reducitur in actum quod sit tota simul, ita nec multitudo figurarum."

22. ". . . numeri pares sunt infiniti; et tamen numeri pares et impares simul accipit sunt plures numeris paribus." (Quodlibetal Question IX, I, 1. In Quaestiones Quodlibetales, cura et studio P. Fr. Raymundi Spiazzi, O.P., [Rome: Marietta, 1956]. See also ST III, 10, 3, ad 3.)

23. “. . . omnem multitudinem oportet esse in aliqua specie multitudinis. Species autem multitudinis sunt secundum species numerorum. Nulla autem species numeri est infinita: quia quilibet numerus est multitudo mensurata per unum. Unde impossibile est esse multitudinem infinitum actu, sive per se, sive per accidens. Item, multitudo in rerum natura existens est creata: et omne creatum sub aliqua certa intentione creantis comprehenditur: non enim in vanum agens aliquod operatur. Unde necesse est quod sub certo numero omnia creata comprehendantur. Impossibile est ergo esse multitudinem infinitam in actu, etiam per accidens." 
The assertions that "every multitude must be in some species of multitude" and that "the species of multitude are according to the species of number" appear to come to:

(1) Every multitude has some (cardinal) number.

On the ground that "every number is multitude measured by one," Aquinas asserts:

(2) There is no infinite (cardinal) number.

And from (1) and (2) he infers:

(3) There is no actually infinite multitude.

The inference is correct, so the conclusion is necessary if the premises are. But even if the necessity of the premises is granted, there is a difficulty: the argument appears to apply to multitudes across the board, including multitudes of things not all of which have actual existence at some one time. Thus it appears to apply to the multitude of past and present human beings; for that multitude, like the multitude of presently existing human beings, must by the first premise have some definite finite number.

The difficulty may be put this way. The word actually occurs in neither premise. Why then should it occur in the conclusion? If the argument from (1) and (2) to (3) is a proof, then surely the argument from (1) and (2) to:

(4) There is no infinite multitude

is also a proof.

Of course, the first premise can be weakened, so that it says only that every actual multitude has some (cardinal) number, where an actual multitude is understood to be one made up of things all of which are at some one time actual. But, except for the fact that it would prevent the inference to (4), it is hard to see the point of the implied restriction. The multitude of monarchs of England is not actual, in the proposed sense; yet, vagueness aside, there have been just so-and-so many of them. It is absurd to say or imply that in counting we must limit ourselves to things that exist at some one time. If they do not exist at some one time, then admittedly they cannot be ticked off one after another by pointing. But to count the monarchs of England one need not point to them.

Whatever Aquinas may have intended, he has in fact given an argument the premises of which imply that there are no infinite multitudes, actual or otherwise. If, as he evidently means to say, the premises are necessary truths, then so is (4). And yet it is supposed to be possible that there should have been infinitely many things in the field of the relation C-possible, in particular, that there should have been infinitely many human beings. The inconsistency appears to remain. 
A standard objection to Aquinas's argument is directed against (2). It is said that, understandably enough, he ignores the fact that there are transfinite cardinal numbers. Cantor appears to have thought this to be the only defect in the argument; in the absence of an adequate theory of transfinite cardinals, the argument was "thoroughly justified." Thus, in reference to Aquinas's argument, Cantor wrote:

The thoughtful arguments which one finds here and with the church fathers (Augustine should be excepted) against the standpoint represented by me were thoroughly justified, and it was therefore right and correct to oppose actually infinite numbers, so long as a principle of individuation, specification and ordination of that actual infinite which I call the transfinite had not been found. However, all these arguments crumbled as soon as one set up such a principle and it had been demonstrated as true. ${ }^{24}$

From what he says about one of Zeno's arguments against plurality, it may be inferred that Gregory Vlastos would echo Cantor's criticism of Aquinas. The relevant part of Zeno's argument reads as follows:

If there are many things, it is necessary that they are just as many as they are, and neither more nor less than that. But if they are as many as they are, they will be limited. 25

And concerning this part of Zeno's argument, Vlastos says that "it is hard to see how anyone could have broken it before the demonstration of transfinite cardinals and superdenumerable sets by Georg Cantor". ${ }^{26}$

While it is no doubt true that Aquinas's argument, and Zeno's, are liable to that objection, I think there is another, more fundamental objection. In both arguments it is assumed that, as Aquinas says, "the species of multitude are according to the species of numbers"- that is, that every multitude of things must be of some definite cardinality, so that there cannot be such-and-such things unless there are so-and-so many of them. Now of course, if there are some cookies in the jar, then, breakage and crumbling aside, there must be some definite number of them: seven, or a dozen, and so on. But it is not obvious that if there are infinitely many natural numbers, or infinitely many points on a straight line in Euclidean

24. Letter to Schlottman of 9 April 1887, Nachlass VI, p. 110. Quoted from Michael Hallett, Cantorian Set Theory and Limitation of Size (Oxford: Clarendon Press, 1984), p. 22.

25. As translated in G. S. Kirk, J. E. Raven, and M. Schofield, The Presocratic Philosophers, 2nd ed. (Cambridge: Cambridge University Press, 1983), p. 266.

26. "Zeno of Elea", in Paul Edwards, ed., The Encyclopedia of Philosophy (New York: Macmillan, 1967), 7:369-79, at 7:371. 
space, then the numbers and the points must be of some definite species of number. Leibniz was not being just incoherent when, on the one hand, he asserted the existence of an actual infinity of monads and, on the other, denied that there are infinite numbers. 27

Of course, Cantor taught us about the alephs, and thereby gave sense to such questions as that concerning the number of points on a line. ${ }^{28}$ Ironically, however, Cantor's own theory of transfinite cardinal numbers requires that not all multiplicities be numerable: there is no saying how many ordinal numbers there are, or how many cardinals, or how many sets. Perhaps Cantor was not perfectly clear on the matter at the time he made his criticism of Aquinas's argument. But he soon came to be. In his famous letter to Dedekind of 28 July 1899, he wrote:

If we start from the notion of a definite multiplicity . . . of things, it is necessary, as I discovered, to distinguish two kinds of multiplicities (by this I always mean definite multiplicities).

For a multiplicity can be such that the assumption that all of its elements "are together" leads to a contradiction, so that it is impossible to conceive of the multiplicity as a unity, as "one finished thing". Such multiplicities I call absolutely infinite or inconsistent multiplicities.

As we can readily see, the "totality of everything thinkable", for example, is such a multiplicity; later still other examples will turn up.

If on the other hand the totality of the elements of a multiplicity can be thought of without contradiction as "being together", so that they can be gathered together into "one thing", I call it a consistent multiplicity or a "set." 29

Thus a well-defined multiplicity, one for which it is determinate which things are in it and which are not, is a set only if it can be conceived as a single thing. And to allow that some well-defined multiplicities are not sets is in effect to allow that, in order for there to be certain objects, it is not necessary that those objects constitute a set. But if they do not, then on Cantor's own theory there is no saying

27. To cite only one passage of many: "Arguments against actual infinity assume, that if this be admitted, there will be an infinite number, and that all infinities will be equal. But it is to be observed that an infinite aggregate is neither one whole, or possessed of magnitude, nor is it consistent with number" (Gottfried Wilhelm Leibniz: Die Philosophischen Schriften, 7 vols., ed. C. I. Gerhardt [Berlin, 1857-1890], 2:304; as translated in Bertrand Russell, A Critical Exposition of the Philosophy of Leibniz, rev. ed. [Cambridge: Cambridge University Press, 1937], p. 110.).

28. See the instructive comments by Kurt Gödel in the opening section of his "What is Cantor's Continuum Problem?," in Philosophy of Mathematics, ed. Paul Benacerraf and Hilary Putnam (Cambridge: Cambridge University Press, 1983), pp. 470-485.

29. Gesammelte Abhandlungen mathematischen und philosophischen Inhalts, ed. E. Zermelo (Berlin: Springer, 1932), p. 443; as translated in Jean van Heijenoort, From Frege to Godel (Cambridge: Harvard University Press, 1967), p. 114. 
how many they are; for on that theory it is only sets that have cardinal numbers. ${ }^{30}$ A multiplicity may thus be definite even though it has no cardinal number.

I do not mean to recommend Cantor's language of "consistent" and "inconsistent" multiplicities, nor his idea that some multiplicities cannot be thought of as one. As Aquinas would have pointed out, $a$ multitude is surely one multitude. ${ }^{31}$ But what I take to be the essential point remains, namely, that from the existence of such-and-such objects one cannot immediately infer that there are so-and-so many of them. Vagueness aside, it would of course be absurd to suggest that finitely many objects of some sort might not be a definite number of objects of that sort: if, as Aquinas held, there are finitely many angels, then there must be just so-and-so many of them. But it is not absurd to say that some infinite multiplicities can be assigned no definite cardinality. There appears to be no saying how many nonselfmembered objects there are, or how many cardinals, or how many ordinals.

Aquinas's second argument seems to me open to the same objection. Even if it is agreed that every multitude in the world is created, and that everything created is comprehended under some definite intention of the Creator, it does not follow that every multitude has a cardinal number. For the Creator's intention is definite if it is an intention to create precisely such-and-such things; it need not be an intention to create thereby so-and-so many things-unless, indeed, every multitude must have some cardinal number. ${ }^{32}$

In his commentary on Aristotle's Physics, Aquinas reports Aristotle's argument against infinite multitudes as follows:

... there is no infinite in multitude. For everything numerable is numbered, and consequently is passed through by being numbered. But every number

30. Compare Hallett, Cantorian Set Theory, p. 169.

31. "Nam et ipsa multitudo non contineretur sub ente, nisi contineretur aliquo modo sub uno" (ST I, 11, 1, ad 2.). I have here as elsewhere quoted the Leonine text. The text of the Blackfriars differs significantly in sense: "Nam et ipsa multa non contineretur sub ente nisi secundum quod aliquo modo continentur sub uno," which is translated "For the many as such cannot be said to exist, except in so far as they have a certain unity" $(2: 158-59)$. No reason is given for the departure from the Leonine text; and, in my judgment, the revision accords ill with the first sentence of the response, which in both versions reads in substantially the same way: "Ad secundum dicendum quod nihil prohibet id quod est uno modo divisum, esse alio modo indivisum; sicut quod est divisum numero, est indivisum secundum speciem: et sic contingit aliquid esse uno modo unum, alio modo multa."

32. The second argument is weak in an additional respect. From the proposition that no agent acts aimlessly (in vanum) it does not follow that an agent's intentions are always definite, in the sense required: a baker does not act aimlessly in baking cookies, but it was not his intention to produce precisely these cookies. 
and every thing which has a number is numerable. Therefore, everything of this sort is passed through. Therefore, if any number, whether separated or existing in sensible things, is infinite, it would follow that it is possible to pass through the infinite, which is impossible. ${ }^{33}$

However, Aquinas expresses dissatisfaction with the argument, on the ground that

one who holds that some multitude is infinite would not say that it is a number or that it has a number. For number adds to multitude the notion [ratio] of a measure. For number is a multitude measured by one, as is said in Metaphysics, X. And because of this number is placed in the species of discrete quantity, whereas multitude is not. Rather multitude pertains to the transcendentals. $^{34}$

Similar misgivings are expressed in the commentary on Aristotle's Metaphysics. There he states:

[Aristotle argues] in the following way that there is no infinite number in sensible things. Every number and everything which has a number is numerable. But nothing numerable is infinite, because what is numerable can be spanned by numeration. Therefore no number is infinite. . . . [But, Aquinas says,] anyone who would claim that there is an infinite multitude would not hold that it is a number, because number is multitude measured by one, as has been explained in Book X. But nothing measured is infinite. ${ }^{35}$

I suppose it is possible that in these passages Aquinas meant only to point out, and not to endorse, what someone might say in response to Aristotle's arguments. But I think this is unlikely. After all, in both places he warns the reader that the argument proceeds from "the common and the probable," and he says in the commentary on Physics that it "does not conclude of necessity." It thus seems

33. Aristotle's argument occurs at Physics 204b7-10. Edward Hussey, in Aristotle's Physics: Books III and IV (Oxford: Clarendon Press, 1983), translates it thus: "Nor, for that matter, can there be a separated infinite number: for number, or what has number, is countable, and so, if it is possible to count what is countable, it would then be possible to traverse the infinite" (p. 10). As for the meaning of 'separated' (kechorismenos), Hussey writes: 'It cannot mean, as choristos ('separable') often does, anything like 'self-subsistent' or 'existing independently of ordinary things'. Apart from the variation of terminology, that sense bears no relation to the argument. The sense required is, rather, 'existing as the number of an actually realized totality', and hence 'separated out' from a mere potentiality ..." (p. 79).

34. In Phys. III, 8 (352), as translated by Blackwell, Spath, and Thirlkel in Commentary on Aristotle's Physics by St. Thomas Aquinas, p. 164.

35. In duodecim libro Metaphysicorum expositio [hereafter In Met.] XI, lect. 10 (2329); as translated by John P. Rowan, St. Thomas Aquinas: Commentary on the Metaphysics of Aristotle (Chicago: Henry Regnery, 1961), p. 830. Aristotle's argument occurs at Metaphysics X, 1066b24-26. 
likely that Aquinas intends to expose some particular point of weakness. Let us try to see what it is supposed to be. ${ }^{36}$

Aquinas says that every plurality, or multitude, results from some division (omnis pluralitas consequitur aliquam divisionem). ${ }^{37}$ But division, he says, can be understood either materially or formally. Material division, in the sense I think he intends, is exemplified in any scattered quantity of stuff. We may imagine a baker who, by certain mixings and stirrings, produces a quantity of cookie dough, and then literally divides it into a number of smaller quantities, in preparation for baking. The dough, which was all of a piece, comes to be in a dozen pieces. It has undergone a change: once undivided, it has become divided. The illustration is not in every respect typical; for scatter need not have an agent, and it need not follow upon an earlier unitary state. In order for there to be material division, it is necessary and sufficient that there be disconnectedness of the quantity in question, however that happens to have obtained.

Being scattered is, for Aquinas, a determinable attribute of which the determinates are, as we might say, being twofold, being threefold, and so on. A divided quantity will have some one of these determinate attributes, and it will therefore be in a certain sense measurable: the degree of its scatter can be discerned by counting the undivided units of the divided quantity of stuff.

Though I can give no decisive textual evidence, I believe it was Aquinas's view that every multitude of material things is consequent upon some material division. So, given any such multitude, there will be an associated quantity of stuff that exemplifies one of the numerical attributes just now mentioned. Hard cases come to mind, of course. If there are on the table a china cup, a tin cup, and a plastic cup, then the cups on the table constitute a multitude of material things. But what is the associated quantity of stuff? Better, what is the stuff? Maybe earth is the answer in this case, but then there will be others in which the only answer will be materia prima.

It is clear in any event that material division obtains only in so far as there is discrete quantity. The associated numerical properties will be exemplified only in material quantities. Aquinas not infrequently says things which imply that number is simply the concept under which fall these various numerical attributes. ${ }^{38}$ Such remarks are unfortunate, because they suggest that he held numerical terms to be inapplicable outside the category of discrete quantity. But this was very far from being his view, as is plain from what he says about the other sort of division.

Formal division is described as "the division which is caused by contradiction, inasmuch as two particular beings are said to be divided by reason of the fact

36. In the following six paragraphs I make use of brief remarks by Geach in Three Philosophers, p. 73 and Logic Matters (Berkeley, Calif. University of California Press, 1972), pp. 213-14. For my use of "quantity' see Helen Morris Cartwright, "Heraclitus and the Bath Water," Philosophical Review 74 (1965): 466-85 and "Quantities," Philosophical Review 79 (1970): 25-42.

37. ST I, 30, 3.

38. See, e.g., De potentia IX, 5, ad 8; In Met. IV, lect. 2 (560) and X, lect. 2 (1939). 
that this being is not that being." 39 Things are divided in this way just by virtue of being distinct, and hence multitudes resulting from formal division may be multitudes of any kind of thing whatever. It is true that Aquinas sometimes says that formal division is "by opposite or diverse forms", thereby suggesting, on account of his well-known views about individuation among material things, that the resulting multitudes are multitudes always of immaterial things. ${ }^{40}$ However, I think the context in which such remarks must be placed is nearly always one in which the issue under discussion concerns the application of numerical terms to immaterial things, where Aquinas would think it especially important to insist that plurality can obtain otherwise than through material division. ${ }^{41}$

Aquinas is thus prepared to contemplate, as he must, a use of numerical terms other than that in which they stand for properties of scattered quantities of matter. Things of any kind may be said to be three, or a dozen-or, as in Daniel's vision, "ten thousand times a hundred thousand." 42 Numerical terms understood this way are accordingly said to be transcendental, in the sense of having an unlimited range of applicability. Though he seems to me not always as explicit on the point as he might be, it is clear that Aquinas must hold that numerical terms, taken transcendentally, can be applied in particular to material multitudes. Indeed, if a scattered quantity is $n$-fold, then there must be $n$ things in the associated multitude: to each predication of a numerical attribute there corresponds what Frege called a statement of number. ${ }^{43}$ Application of transcendental numerical terms to

39. In Met. X, lect. 4 (1997).

40. For instance at $S T$ I, 30, 3. See also De potentia IX, 7, where Aquinas says that the kind of division in question arises "by some formal opposition" (per aliquam oppositionem formalem).

41. The only exception I am aware of occurs in In Phys. III, lect. 12 (394), where formal division is said to be caused "by opposites." The entire passage is of interest, not only for this reason but also because of what is said in it about infinite number and multitude. In the translation by Blackwell et al. it reads: " . . . it must be noted that division . . . causes multitude. However, division is twofold; one is formal, which is by opposites, and the other is according to quantity. Now the first division causes multitude, which pertains to the transcedentals insofar as being is divided into the one and many. But the division of continuous quantity causes number, which is a species of quantity insofar as it has the nature [ratio] of a measure. And this number can be multiplied just as magnitude is divisible to infinity. But the multitude which follows from the formal division of things is not multiplied to infinity. For the species of things are determinate, just as also there is a determinate quantity in the universe. And thus [Aristotle] says that this number which is multiplied to infinity is not separated from the division of the continuous. Moreover, this number is not infinite as something permanent, but as always existing in 'coming to be', insofar as we successively add to some given number" (p. 181). I am uncertain about the proper interpretation, especially in view of Aquinas's criticism of Aristotle's argument against actually infinite multitude, shortly to be discussed. Perhaps the passage is intended to be simply elucidatory of Aristotle.

42. Dan. 7:10, to which Aquinas refers in ST I, 50, 3, sed contra. In the Vulgate the phrase is "decies millies centena millia." In The New American Bible: "myriads upon myriads".

43. See Grundlagen der Arithmetik (Breslau: Koebner, 1884), Sect. 45-54. 
material multitudes is in fact implicit in Aquinas's remark that "immaterial substances exceed material substances in multitude, as it were incomparably" (substantiae immateriales excedant secundum multitudinem substantias materiales, quasi incomparabiliter). 44

Now, it is hard to avoid the conclusion that when Aquinas says (in criticism of Aristotle's argument) that "one who holds that some multitude is infinite would not say that it is a number or has a number," the term number is to be understood as applicable to divided quantities. Aquinas further states that "this number is placed in the species of discrete quantity," and he concludes with the remark that "multitude [in contrast] pertains to the transcendentals." His criticism seems to come to this: someone who holds that there is an infinite multitude would of course not suppose it to be numbered in the way the cookie dough is; when it is said that there are infinitely many things of some kind, 'many' is therefore to be taken transcendentally; infinite multitudes, thus understood, have not been shown to be impossible.

But if this is a weakness in Aristotle's argument, then it is hard to see how it is not also a weakness in the first of Aquinas's arguments against the possibility of actually infinite multitudes. Recall that he argued that

every multitude must be in some species of multitude. Now the species of multitude are according to the species of numbers. But no species of number is infinite, for every number is multitude measured by one. Hence it is impossible that there be an actually infinite multitude.

How is 'number' to be understood here? The only clue is the Aristotelian dictum that "every number is multitude measured by one." But that dictum occurs in Aquinas's comments on Aristotle's argument, and there it seems to be taken to indicate that in the argument "number is placed in the species of discrete quantity."

True, we have just now seen that in his commentary on Aristotle's Metaphysics, Aquinas says simply that "anyone who would claim that there is an infinite multitude would not hold that it is a number, because number is multitude measured by one": talk of number as being in the category of quantity does not occur, nor is a contrast drawn between 'number' in that sense and 'multitude' in the transcendental sense. It may therefore be suggested that when, in the passage from the commentary on Metaphysics, Aquinas says that "every number is multitude measured by one," he means to speak of number understood transcendentally. I will not contest the exegetical point. But I do not see that it helps. If, as Aquinas evidently thinks, the dictum implies that there are no transfinite numbers, then, he seems to say, the advocate of actually infinite multitudes will simply deny their numerability: Aristotle can have (2), but then he cannot have (1). But then how is it that Aquinas can have both? 


\section{VI}

One of Bonaventure's purported demonstrations of the noneternity of the world goes as follows. If the world did not begin, then already there have been infinitely many human beings, "for all things are in a certain way for the sake of man and a man lasts only for a limited length of time." But then there are even now infinitely many rational souls, for rational souls are incorruptible and each human being has had one. Hence if the world did not begin, there are infinitely many rational souls. But "it is impossible that there be simultaneously an infinite number of things." 45

Bonaventure was not the first to give the argument, and maybe that is why Aquinas does not credit it to him. ${ }^{46}$ But Aquinas responds to the argument-as indeed he must, given that he thinks it an article of faith that the world did begin. Of the three responses known to me, ${ }^{47}$ the most interesting in the present context is the one that occurs near the end of De aeternitate mundi, which I have cited in another connection. It reads:

One of [the purported demonstrations of the noneternity of the world] is fairly difficult; it concerns the infinite number of souls: if the world has existed forever, the number of souls must now be infinite. But this argument is not to the purpose, because God could have made the world without men and souls: or He could have made men at the time $\mathrm{He}$ did make them, even though $\mathrm{He}$ had made all the rest of the world from eternity. Thus the souls surviving their bodies would not be infinite. Besides, no demonstration has as yet been forthcoming that God cannot produce a multitude that is actually infinite. 48

I have no idea why Aquinas says that the argument is "fairly difficult," for he seems to have at hand a quite adequate response. ${ }^{49}$ But it is the last sentence that is especially baffling. If there has not yet been a demonstration that God cannot produce an actually infinite multitude, then there cannot yet have been a demonstration that an actually infinite multitude is impossible. For, as Aquinas says at ST I, 25, 4, "nothing that implies a contradiction falls under the scope of God's

45. See Vollert, et al., On the Eternity of the World, pp. 108-9.

46. Maimonides attributes it to "one of the modern Mutakallemim." See Guide for the Perplexed I, 74, Seventh Argument.

47. In addition to the passage that follows, these are: ST I, 46, 2, ad 8 and Summa contra gentiles II, 38, ad 6.

48. Vollert, et al., On the Eternity of the World, p. 25.

49. At Summa contra gentiles II, 38, ad 6, the same argument is said to be "more difficult" than certain others. But there the whole response is pretty clearly dialectical: Aquinas is content to say, among other things, that "some do not think it impossible that there are actual infinities in those things which do not have an order" (Quidam vero pro inconvenienti non habent quod sint aliqua infinita actu in his quae ordinem non habent). At $S T$ I, 46, 2 ad 8 Aquinas cites that view but, in apparent reference to $S T$ I, 7, 4, says that it has earlier been shown to be impossible. 
omnipotence" (sub omnipotentia Dei non cadit aliquid quod contradictionem implicat). But then what of the argument in ST I, 7, 4?

Authorities say that De aeternitate mundi is a late work, almost certainly later than Part I of Summa theologiae. ${ }^{50}$ Is that last sentence just a polemical thrust? Or did Aquinas change his mind?

50 See I. T. Eschmann, "A Catalogue of St. Thomas's Works", in Etienne Gilson, The Christian Philosophy of St. Thomas Aquinas (New York: Random House, 1966), pp. 381-430, especially at pp. 387 and 410. Also, James A. Weisheipl, Friar Thomas D'Aquino: His Life, Thought, and Work (New York: Doubleday, 1974), at pp. 361 and 385. 
